\title{
THE ENHANCEMENTS SKILL OF WRITING POETRY BY DWA (DIRECTED WRITING ACTIVITY) STRATEGY
}

\section{Galuh Lukitasari, Siti Wahyuningsih, Tri Budiharto}

Universitas Sebelas Maret

galuhlukita@gmail.com

\section{Article History}

accepted 09/07/2018

approved 01/08/2018

published 17/09/2018

\section{Keywords}

writing skill, writing poetry, DWA (Directed Writing

Activity) Strategy

\begin{abstract}
The purpose of this research was to improve the skill of writing poetry by applied DWA (Direct Writing Activity) Strategy for fifth grade students in SDN Munggung 1 Surakarta on academic year of 2018/2019. The form of this research was a Classroom Action Research which conducted in two cycles. Each cycle consisted of four stages i.e. planning, action, observation, and reflection. The subjects of this research included teacher and 33 fifth grade students in SDN Munggung 1 Surakarta. The data collected by interview, observation, test, and documentation techniques. The data validity test were using content validity, triangulation of resource, and triangulation of technique. The result of this research shows the improvement of skill of writing poetry values from pre-action, cycle I until cycle II.
\end{abstract}

Social, Humanities, and Education Studies (SHEs): Conference Series https://jurnal.uns.ac.id/shes

p-ISSN 2620-9284 e-ISSN 2620-9292 


\section{PENDAHULUAN}

Pembelajaran dengan materi Bahasa Indonesia merupakan aktivitas belajar yang dilakukan oleh guru dan peserta didik pada jenjang sekolah dasar sampai jenjang pendidikan tinggi. Prinsip tujuan pengajaran bahasa adalah agar para peserta didik terampil berbahasa, yaitu terampil menyimak, terampil berbicara, terampil membaca, dan terampil menulis. Kehidupan modern ini, jelas bahwa keterampilan menulis sangat dibutuhkan. Kiranya tidaklah terlalu berlebihan bila kita katakan bahwa keterampilan menulis merupakan suatu ciri dari orang yang terpelajar atau bangsa yang terpelajar. Salah satu keterampilan menulis yang harus dikuasai oleh peserta didik adalah keterampilan menulis puisi.

Keterampilan ialah kegiatan yang berhubungan dengan urat-urat syaraf dan otototot (neuromuscular) yang lazimnya tampak dalam kegiatan jasmaniah seperti menulis, mengetik, olahraga, dan sebagainya (Syah, 2014: 117). Menurut Gutiérrez, dkk (2015: 49), "... writing skill is a cognitive process (White \& Arndt, 1991) that involves the activation of a series of non-linear mental operations (Hedge, 2005) to organize and arrange the ideas on a piece of paper". Pendapat tersebut dapat diartikan bahwa keterampilan menulis merupakan proses kognitif yang melibatkan pengaktifan serangkaian operasi mental non-linear untuk mengatur gagasan di selembar kertas. Nofal dalam International Journal of Bussinesand Social Science menyatakan bahwa: "Sentence structure and phrase structure in the poetic language is different from those of any literaly genre and is similar to those of spoken code. Poets permit themselves considerable freedom in word order for certain purposes, e.g. emphasis, front fokus, end fokus, end weigth or rhyme ... etc, for syntax is similar to that of the spoken language" (2011: 62). Pendapat tersebut dapat diartikan bahwa struktur kalimat dalam puisi memiliki perbedaan dengan karya sastra yang lain. Dalam penulisannya penyair/penulis memiliki kebebasan dalam menyusun urutan kata yang akan digunakan dalam penulisan untuk mencapai tujuan tertentu. Oleh sebab itu puisi memiliki karakteristik yang berbeda dari karya yang lain karena merupakan sebuah karya yang berasal dari hasil pemikiran sang penulis.

Pendapat tersebut dapat diartikan bahwa struktur kalimat dalam puisi memiliki perbedaan dengan karya sastra yang lain. Dalam penulisannya penyair/penulis memiliki kebebasan dalam menyusun urutan kata yang akan digunakan dalam penulisan untuk mencapai tujuan tertentu. Oleh sebab itu puisi memiliki karakteristik yang berbeda dari karya yang lain karena merupakan sebuah karya yang berasal dari hasil pemikiran sang penulis..

Hasil tes sebelum tindakan yang menunjukkan bahwa sekitar 27,27\% (9 peserta didik) memperoleh nilai di atas KKM (Kriteria Ketuntasan Minimal), dan 72,72\% (24 peserta didik) mendapatkan nilai di bawah KKM yang telah ditetapkan yaitu 70. Data tersebut membuktikan bahwa pembelajaran Bahasa Indonesia yaitu pada materi puisi kelas V SD Negeri Munggung 1 Surakarta masih belum maksimal. Sebagian besar peserta didik masih merasa kurang untuk puisi yang mereka buat karena peserta didik masih kesulitan dalam menentukan kata dan menuangkan pemikiran mereka ketika menulis puisi.

Berdasarkan hasil tes pra-tindakan di atas perlu dilakukan upaya peningkatan keterampilan menulis puisi. Usaha peningkatan keterampilan menulis puisi dapat dilakukan dengan strategi DWA (Directed Writing Activity). Strategi tersebut membuat peserta didik menulis sesuai dengan tahapan menulis yang sistematis, sehingga guru bisa memberikan bimbingan secara langsung pada setiap tahap.

Strategi DWA (Directed Writing Activity) menurut Blake dan Spennato dalam Eanes (1997: 478) adalah salah satu strategi untuk mengembangkan keterampilan 
menulis dengan menggunakan pendekatan menulis dalam penerapannya. Tahapantahapan strategi DWA (Directed Writing Activity) antara lain: 1) Pramenulis (prewriting); 2) pengedrafan (drafting); 3) perbaikan (revising); 4) penyuntingan (editing); 5) pemublikasian (publishing). Strategi ini akan membiasakan siswa untuk menulis sesuai dengan tahapan menulis yang baik dan benar, dan peserta didik akan turut serta secara langsung dalam aktivitas menulis dengan tahapan yang sistematis.

Strategi DWA (Directed Writing Activity) membantu siswa menjadi penulis yang baik. Penulis yang baik akan melewati kelima tahapan proses menulis. Hal ini didukung dengan pendapat dari Sillin dan Chan (2015: 256) yang menyatakan bahwa: "These models describe the writing process as a linear series of stages, separated by time and characterized by the gradual development of the written product. The introduction of these models helped to improve the teaching of writing by highlighting the importance of planning in the writing process... To date studies indicate that the writing process is one effective way to teach students to be good writer".

Kelebihan strategi DWA (Directed Writing Activity) menurut Blake dan Spennato dalam Eanes (1997: 478) meliputi: 1) dapat diterapkan pada pembelajaran semua jenjang, baik jenjang sekolah dasar, sekolah lanjutan, dan juga di perguruan tinggi.; 2) Strategi ini menggunakan pendekatan menulis dalam penggunaannya, sehingga siswa akan berlatih menulis dengan baik sesuai prsedur yang sudah ditetapkan; 3) Strategi DWA (Directed Writing Activity) dapat diterapkan dalam semua jenis pembelajaran mengarang. Strategi ini juga membuat peserta didik dapat berperan langsung dalam proses pembelajaran. Selain itu dapat menumbuhkan sikap kritis dan berpikir kreatif siswa. Kegiatan revising memberi kesempatan kepada siswa untuk berkomentar pada hasil tulisan temannya.

Berdasarkan uraian tersebut, peneliti melakukan penelitian dengan judul "Peningkatan Keterampilan Menulis Puisi Melalui Strategi DWA (Directed Writing Activity) Siswa Kelas V SD Negeri Munggung 1 Surakarta Tahun Ajaran 2017/2018". Peneliti juga menyusun rumusan masalah penelitian yaitu "Apakah penerapan strategi DWA (Direct Writing Activity) dapat meningkatkan keterampilan menulis puisi siswa kelas V SD Negeri Munggung 1 Surakarta Tahun Ajaran 2017/2018?" Sesuai dengan rumusan masalah tersebut, penelitian ini bertujuan untuk meningkatkan keterampilan menulis puisi melalui penerapan strategi DWA (Directed Writing Activity) siswa kelas V SD Negeri Munggung 1 Surakarta Tahun Ajaran 2017/2018.

\section{METODE}

Penelitian ini berupa Penelitian Tindakan Kelas (PTK) yang dilakukan di SD Negeri Munggung 1 Surakarta pada bulan Januari-Juni 2018. Subjek penelitian ini adalah siswa kelas $\mathrm{V}$ yang berjumlah 33 siswa, terdiri dari 13 siswa laki-laki dan 20 siswa perempuan. Semua siswa di kelas $\mathrm{V}$ memiliki kondisi fisik dan kejiwaan yang sehat, dengan kata lain tidak ada siswa yang cacat.

Teknik pengumpulan data yaitu melalui observasi, wawancara dan doku-mentasi. Uji validitas data dilakukan dengan triangulasi dan validitas isi. Penelitian ini menggunakan teknik analisis data model interaktif Miles dan Huberman dalam Sugiyono (2015: 337) yang terdiri dari tiga tahap, yaitu data reduction, data display, dan conclusion drawing/verification.

Indikator kinerja penelitian ini adalah peningkatan keterampilan menulis puisi siswa dalam mata pelajaran Bahasa Indonesia dengan keter-capaian target $80 \%$ jumlah siswa di kelas. Peningkatan keterampilan menulis puisi yang diukur malalui tes yang memiliki penilaian dari aspek: 1) Penyampaian gagasan; 2) Pemilihan kata; 3) 
Koherensi atau ketepatan; 4) Ketepatan judul dengan isi; 5) Rima dengan irama (Rukayah $(2012,123)$ ).

\section{HASIL DAN PEMBAHASAN}

Penelitian ini dilakukan selama 2 siklus. Masing-masing siklus terdiri dari 2 kali pertemuan dengan alokasi waktu 2 × 35 menit dan $2 \times 35$ menit. Materi yang dipelajari pada penelitian ini adalah pengertian puisi, unsur-unsur puisi dan langkah-langkah menulis puisi.

Analisis data hasil observasi kinerja guru pada kegiatan siklus I dan siklus II dapat dikatakan mengalami peningkatan yang signi-fikan dibandingkan pada kegiatan pra-siklus. Skor pada kegiatan pra-siklus sejumlah 2,7 (baik) mengalami peningkatan skor dengan mendapatkan skor sejumlah 3,6 (baik) pada siklus I dan 3,9 (baik) pada siklus II seperti yang ditampilkan pada Gambar 1.

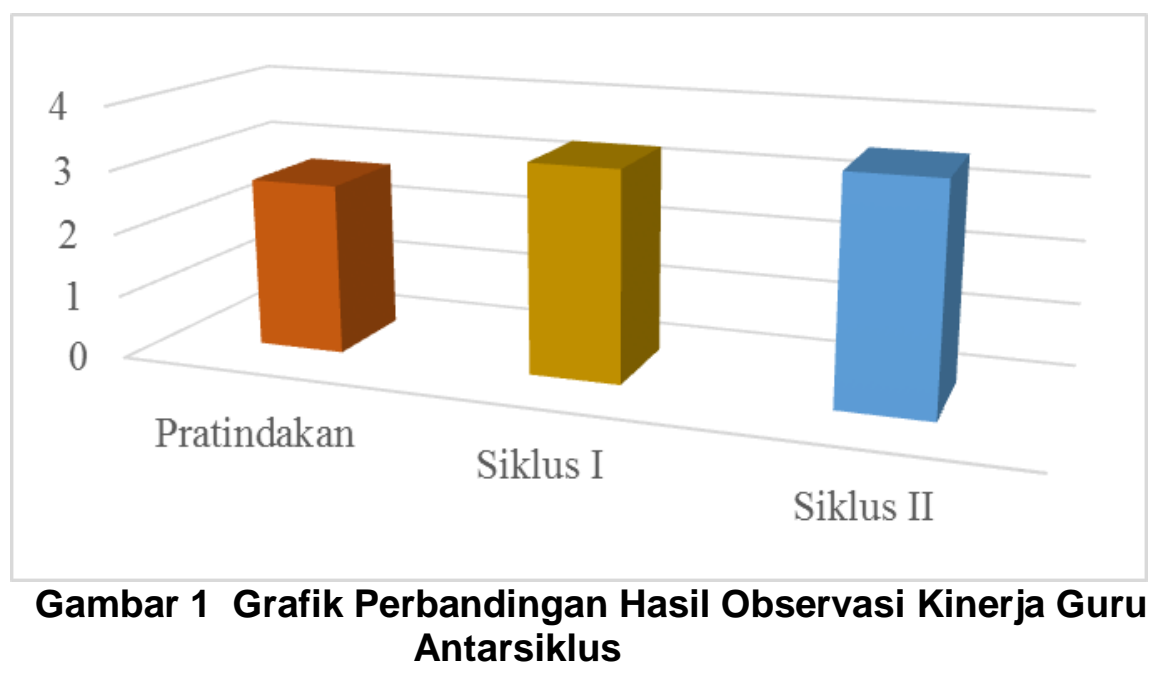

Pada kegiatan pra-siklus, guru sudah baik dalam mengajar namun masih ditemukan kekurangan dalam pemanfaatan media dan peserta didik kurang antusias dalam pembelajaran, sedangkan setelah dilakukan tindakan dengan menerapkan strategi DWA pada siklus I dan siklus II kinerja guru mendapatkan skor yang lebih baik dibandingkan pada pra-siklus. Peserta didik menunjukkan antusias yang lebih baik ketika kegiatan pembelajaran berlangsung dengan menerapkan strategi DWA. Perbandingan aktivitas peserta didik dapat dilihat pada Gambar 2.

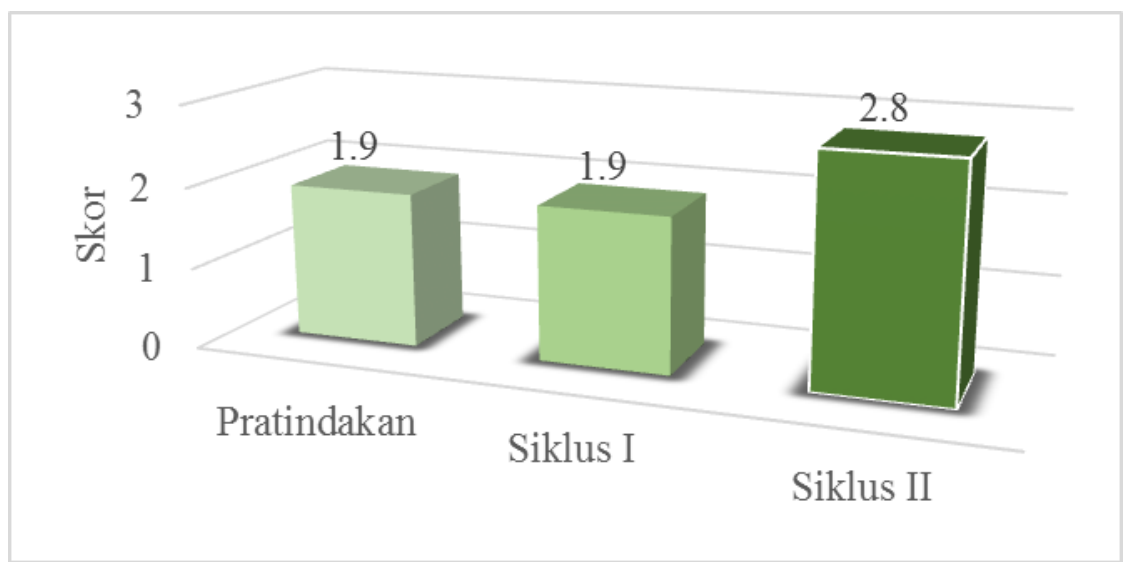

Gambar 2 Grafik Perbandingan Hasil Observasi Aktivitas Siswa Antarsiklus 
Dapat diketahui dari gambar 2 bahwa aktivitas siswa tidak mengalami peningkatan dari pratindakan ke siklus I, dan mengalami peningkatan pada siklus II. Pada pratindakan, aktivitas siswa dalam kategori cukup baik dengan skor 1,9. Pada siklus I belum mengalami peningkatan dengan perolehan skor 1,9 dikategori cukup baik. Aktivitas peserta didik mengalami peningkatan pada siklus II dengan skor 2,8 dan mendapat kategori baik. Dengan demikian, ada peningkatan aktivitas peserta didik dari kondisi awal yang cukup baik menjadi baik di akhir tindakan..

Peningkatan juga terjadi terhadap nilai tes keterampilan menulis puisi peserta didik. Nilai rata-rata kelas, ketuntasan klasikal, nilai tertinggi dan nilai terendah mengalami peningkatan dari kegiatan pra-siklus ke siklus I dan siklus II. Perbandingan Hasil Keterampilan Menulis Puisi Antarsiklus dapat dilihat pada Gambar 3.

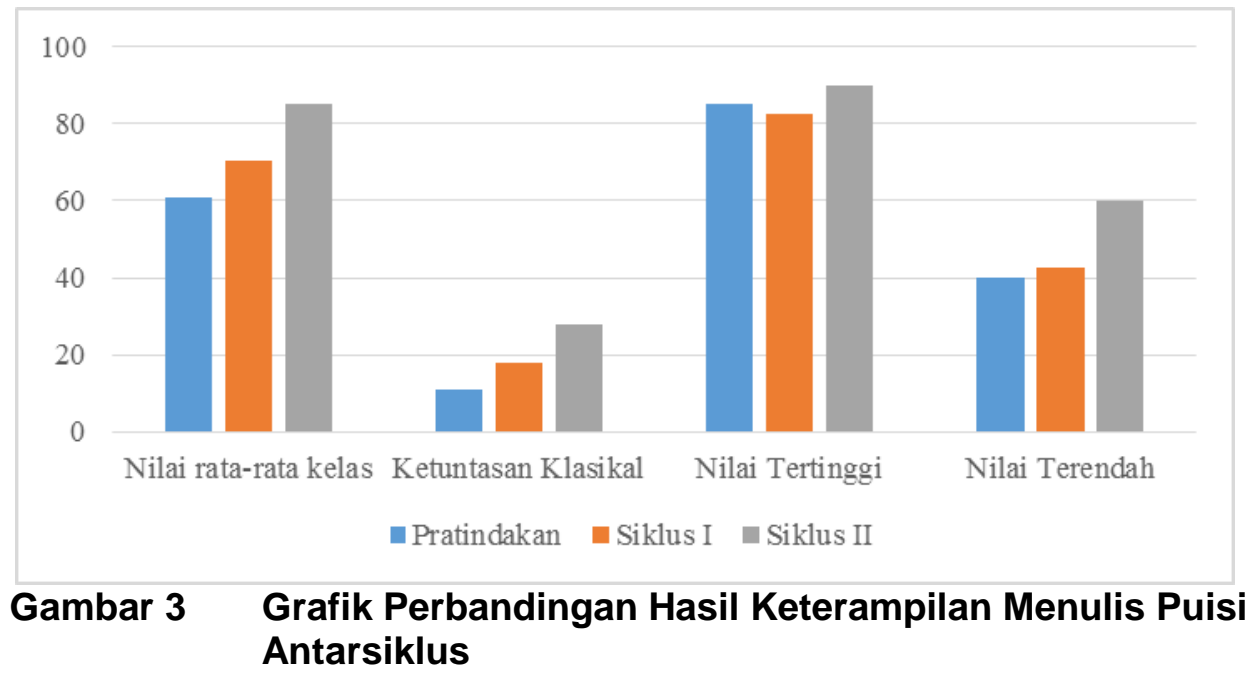

Hasil penelitian menunjukkan adanya peningkatan pada setiap tindakan mulai dari pratindakan, siklus I, dan siklus II. Peningkatan terjadi pada nilai rata-rata kelas, persentase ketuntasan, kinerja guru, dan aktivitas siswa. Penelitian Tindakan Kelas ini dilaksanakan dalam dua siklus dan menerapkan strategi DWA (Directed Writing Activity) untuk meningkatkan keterampilan menulis puisi. Menurut Blake dan Spennato dalam Eanes (1997: 478), strategi DWA (Directed, Writing, Activity) adalah salah satu strategi untuk mengembangkan keterampilan menulis dengan menggunakan pendekatan proses menulis. Diterapkannya strategi ini dapat membantu guru dan peserta didik untuk aktif pada setiap tahapan menulis.

Kondisi awal sebelum diterapkannya strategi DWA (Directed Writing Activity), keterampilan menulis puisi peserta didik masih rendah yang dapat dilihat dari nilai uji pratindakan dan juga dari wawancara dengan guru sebelum tindakan yang menunjukkan bahwa peserta didik tidak terlalu menyukai materi menulis pada pelajaran Bahasa Indonesia sehingga mereka kurang antusias dan cenderung malas. Dengan kondisi tersebut, persentase ketuntasan klasikal pada pratindakan hanya sebesar $27,27 \%$ (9 anak), sedangkan persentase peserta didik yang mendapatkan nilai dibawah KKM (70) sebesar 72,73\% (24 anak). Pembelajaran menulis sebelum dilaksanakan tindakan belum optimal karena strategi atau media pembelajaran yang digunakan guru kurang inovatif, salah satunya dengan mendikte. Siswa menjadi kurang kreatif dalam menuangkan ide yang dia punya. Melalui wawancara dengan peserta didik diketahui juga bahwa peserta didik masih kesulitan dalam memilih kata yang akan mereka gunakan dalam pembelajaran menulis. Hal tersebut dapat 
dibuktikan dari hasil kinerja guru dengan skor 2,7 (kategori baik) dan hasil aktivitas siswa dengan skor 1,9 (kategori cukup baik).

Setelah siklus I dilaksanakan, terjadi peningkatan persentase ketuntasan klasikal. Persentase ketuntasan klasikal pada pratindakan diperoleh sebesar 27,27\% (9 peserta didik) dan meningkat pada siklus I menjadi 54,5\% (18 peserta didik). Peserta didik mulai tertarik terhadap pembelajaran menulis puisi dengan diterapkannya strategi DWA (Directed Writing Activity) ketika pembelajaran. Hal ini terjadi karena peserta didik terfasilitasi oleh guru berupa bimbingan dan arahan yang selalu diberikan disertai umpan balik sehingga dapat segera dilakukan perbaikan. Peserta didik di dibimbing dan diarahkan oleh guru untuk menulis sesuai dengan langkah-langkah menulis yang baik dengan bantuan media gambar. Bimbingan diberikan secara berkelanjutan sehingga kebutuhan peserta didik terhadap kemampuan menulis dapat terpantau dengan baik dan dapat segera diperbaiki apabila mengalami kekurangan.

Hasil keterampilan menulis puisi peserta didik dipantau oleh guru melalui draf awal yang dibuat peserta didik pada pertemuan pertama. Setelah draf awal diperiksa oleh guru, pada pertemuan kedua tulisan siswa tersebut direvisi dengan menggunakan bantuan lembar kritik dan saran yang dilakukan oleh kelompok berpasangannya. Pada siklus I peserta didik masih sedikit kesulitan mengisi lembar kritik dan saran untuk merevisi tulisan teman. Guru terus membimbing peserta didik dalam penggunaan lembar kritik dan saran tersebut. Dengan demikian, peserta didik dapat terfasilitasi sehingga siswa dapat meningkatkan keterampilan menulis puisi yang dapat dilihat dengan nilai tes menulis puisi peserta didik. Pada siklus I kinerja guru meningkat menjadi 3,3 (kategori baik) dan aktivitas peserta didik belum meningkat, masih pada skor 1,9 (kategori cukup baik).

Pelaksanaan pada siklus II guru meningkatkan intenstas bimbingan setiap tahapan menulis. Peserta didik sudah memahami bagaimana mengisi lembar kritik dan saran sehingga dapat membimbing siswa untuk merevisi hasil tulisan awalnya. Penerapan strategi DWA (Directed Writing Activity) mampu membimbing peserta didik dalam menulis secara bertahap dan baik. Hal tersebut diperkuat dengan hasil wawancara dengan guru kelas bahwa penerapan strategi DWA sudah sesuai dengan karakteristik siswa. Guru kelas V berpendapat bahwa strategi DWA merupakan strategi yang efektif dan tepat untuk meningkatkan keterampilan menulis puisi karena peserta didik selalu dibimbing dalam setiap tahapan menulis, dan peserta didik menjadi tahu bagaimana urutan menulis yang baik.

Hasil observasi pada siklus II, kinerja guru meningkat menjadi 3,9 (kategori baik), sedangkan untuk aktivitas peserta didik meningkat menjadi 2,8 (kategori baik). Masih terdapat 5 peserta didik yang belum tuntas atau setara dengan 15,2\%. Hal tersebut dikarenakan peserta didik masih kesulitan memilih kata yang akan mereka gunakan untuk menulis puisi. Selain itu, susunan kata per baris pada puisi juga belum saling berhubungan maknanya. Persentase klasikal ketuntasan siklus II sudah mencapai indikator kinerja penelitian yang ditetapkan sebesar $80 \%$ sehingga penelitian tindakan kelas ini dihentikan pada siklus II, karena telah mencapai indikator kinerja penelitian.

Penelitian tindakan kelas ini telah dilaksanakan sesuai dengan langkah-langkah penerapan strategi DWA (Directed Writing Activity) dalam pembelajaran menulis puisi, sehingga dapat menjawab rumusan masalah yang telah dikemukakan oleh peneliti. Dengan demikian, dapat disimpulkan bahwa penerapan strategi DWA (Directed Writing 
Activity) dapat meningkatkan keterampilan menulis puisi siswa kelas V SDN Munggung 1 Surakarta tahun ajaran 2017/2018.).

\section{SIMPULAN}

Berdasar pada hasil penelitian tindakan kelas yang sudah dilaksanakan selama dua siklus untuk pelajaran Bahasa Indonesia materi menulis puisi dengan menerapkan strategi DWA (Directed Writing Activity) pada siswa kelas V SD Negeri Munggung 1 Surakarta, dapat ditarik kesimpulan bahwa penerapan strategi DWA (Directed Writing Activity) dapat meningkatkan keterampilan menulis puisi siswa kelas V SD Negeri Munggung 1 Surakarta tahun ajaran 2017/2018.

Berkaitan dengan hasil penelitian, peneliti mengajukan saran 1) bagi guru, hendaknya mempertimbangkan penggunaan strategi DWA (Directed Writing Activity) dalam pembelajaran menulis, karena strategi ini dapat melatih peserta didik menjadi penulis yang baik dan menjadi lebih aktif ketika pembelajaran sedang berlangsung; 2) bagi sekolah, hendaknya menyediakan fasilitas yang berkontribusi dalam menerapkan proses belajar mengajar yang inovatif $n$; 3) peneliti yang ingin meneliti masalah yang sama dihara dapat fokus dalam hal pengkajian teori-teori yang berkaitan dengan penerapan strategi DWA (Directed Writing Activity).

\section{DAFTAR PUSTAKA}

Eanes, R. (1997). Content Area Literacy. Boston: Delmar Publisher.

Gutiérrez, dkk. (2015). Using Pictures Series Technique to Enhance Narrative Writing among Ninth Grade Students at Institución Educativa Simón Araujo. International Journal of English Languange Teaching. Vol. 8, No. 5

Nofal, K. H. (2011). Syntatic Aspects of Poetry: A Pragmatic Perspective. International Journal of Bussines and Social Science, Vol. 2, No. 16.

Rukayah. (2013). Pedoman Pelaksanaan Menulis dengan Pendekatan Whole Language di Sekolah Dasar. Surakarta: UNS Press.

Sillin dan Chan, Andrea. (2015). Effectiveness of the English Writing Process for Postsecondary School Students. International Journal of English Languange Education. Vol. 3, No. 1.

Sugiyono. (2015). Metode Penelitian Pendidikan (Pendekatan Kuantitatif, Kualitatif, dan $R \& D)$. Bandung: Alfabeta.

Syah, M. (2013). Psikologi Pendidikan dengan Pendekatan Baru. Bandung: PT Remaja Rosdakarya Offset Chin, C. (2001). Learning in Science: What Do Students's Questioning Tell Us About Their Thinking. Education Journal, 29 (2), 85-103. 